\title{
Laboratory evaluation of the effect of nitric acid uptake on frost point hygrometer performance
}

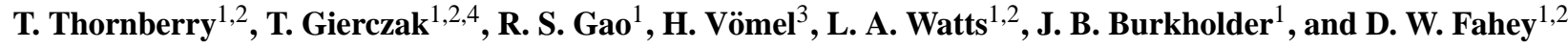 \\ ${ }^{1}$ NOAA Earth System Research Laboratory, Chemical Sciences Division, Boulder, CO, USA \\ ${ }^{2}$ Cooperative Institute for Research in Environmental Sciences, University of Colorado, Boulder, CO, USA \\ ${ }^{3}$ Meteorologisches Observatorium Lindenberg, German Weather Service, Lindenberg, Germany \\ ${ }^{4}$ University of Warsaw, Department of Chemistry, Warsaw, Poland
}

Received: 25 June 2010 - Published in Atmos. Meas. Tech. Discuss.: 24 August 2010

Revised: 3 January 2011 - Accepted: 25 January 2011 - Published: 15 February 2011

\begin{abstract}
Chilled mirror hygrometers $(\mathrm{CMH})$ are widely used to measure water vapour in the troposphere and lower stratosphere from balloon-borne sondes. Systematic discrepancies among in situ water vapour instruments have been observed at low water vapour mixing ratios $(<5 \mathrm{ppm})$ in the upper troposphere and lower stratosphere (UT/LS). Understanding the source of the measurement discrepancies is important for a more accurate and reliable determination of water vapour abundance in this region. We have conducted a laboratory study to investigate the potential interference of gas-phase nitric acid $\left(\mathrm{HNO}_{3}\right)$ with the measurement of frost point temperature, and consequently the water vapour mixing ratio, determined by $\mathrm{CMH}$ under conditions representative of operation in the UT/LS. No detectable interference in the measured frost point temperature was found for $\mathrm{HNO}_{3}$ mixing ratios of up to $4 \mathrm{ppb}$ for exposure times up to $150 \mathrm{~min} . \mathrm{HNO}_{3}$ was observed to co-condense on the mirror frost, with the adsorbed mass increasing linearly with time at constant exposure levels. Over the duration of a typical balloon sonde ascent (90-120 min), the maximum accumulated $\mathrm{HNO}_{3}$ amounts were comparable to monolayer coverage of the geometric mirror surface area, which corresponds to only a small fraction of the actual frost layer surface area. This small amount of co-condensed $\mathrm{HNO}_{3}$ is consistent with the observed lack of $\mathrm{HNO}_{3}$ interference in the frost point measurement because the $\mathrm{CMH}$ utilizes significant reductions $(>10 \%)$ in surface reflectivity by the condensate to determine $\mathrm{H}_{2} \mathrm{O}$.
\end{abstract}

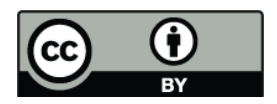

Correspondence to: $\mathrm{T}$. Thornberry (troy.thornberry@noaa.gov)

\section{Introduction}

Water vapour is the most important greenhouse gas in the atmosphere. Changes in its atmospheric abundance are a principal feedback mechanism in the radiative forcing of climate (Held and Soden, 2000; Soden and Held, 2006; Trenberth et al., 2007; Dessler et al., 2008). Knowledge of the distribution of water vapour and how it is changing as the earth system changes is especially important in the upper troposphere and lower stratosphere (UT/LS) where water vapour plays critical roles in atmospheric radiative balance, cirrus cloud formation, and photochemical processes (Forster and Shine, 2002; Gettelman et al., 2004; Solomon et al., 2010). Dehydration processes reduce water vapour mixing ratios to part per million ( $\mathrm{ppm}$ ) values in the tropical UT/LS. The microphysics related to dehydration and cirrus cloud particle nucleation and growth are poorly understood at present (Jensen et al., 2005; Peter et al., 2006), limiting the ability to accurately model the dehydration process and, hence, our ability to estimate the influence of climate change on the UT/LS water vapour distribution. Part of this limitation derives from the uncertainties in available water vapour measurements in the 1 to $10 \mathrm{ppm}$ range typical of this region of the atmosphere. Over the past several decades, there has been considerable disagreement ( $25-100 \%)$ among in situ water vapour measurements by different instruments made at low mixing ratios in the UT/LS. The reasons for the observed differences in measured water vapour in the UT/LS are actively under investigation. A recent, chamber-based intercomparison of the principal in situ UT/LS water vapour instruments (AquaVIT, https://aquavit.icg.kfa-juelich.de/AquaVit/AquaVitWiki) revealed far less disagreement, indicating the differences observed in the atmosphere are likely related to the use of these

Published by Copernicus Publications on behalf of the European Geosciences Union. 
instruments on moving platforms or interferences from other atmospheric trace species.

One of the principal instruments currently used to measure atmospheric water vapour is the chilled mirror hygrometer (Oltmans et al., 2000a). A 30-yr record of balloonborne $\mathrm{CMH}$ measurements provides important constraints on the evolving trend of stratospheric water vapour abundances, which have an important role in climate change (Oltmans et al., 2000b; Rosenlof et al., 2001; Solomon et al., 2010; Hurst et al., 2011). Observed decadal differences in the trend analysis of less than $1 \mathrm{ppm}$ require high confidence in the calibration stability and the absence of measurement interferences in the $\mathrm{CMH}$ technique. The $\mathrm{CMH}$ technique utilizes the principle of condensation of water vapour as a liquid or solid on a chilled mirror. The temperature of the mirror is controlled in order to maintain a constant optical scattering from a thin dew or frost layer in contact with water vapour in an ambient sample flowing continuously past the mirror. An optical detector measures the specular reflectivity of the condensate-covered mirror, while a feedback controller regulates the mirror temperature such that the measured reflectivity of the mirror remains constant. Under this condition, the condensate layer on the mirror is maintained in approximate thermal equilibrium with the water vapour in the air passing over the mirror. The mirror temperature is then assumed to be equal to the ambient dew point or frost point temperature. The water vapour partial pressure is calculated from this measurement using a formulation of the ClausiusClapeyron equation for the saturation pressure over water or ice, and subsequently the water vapour mixing ratio is calculated by dividing by the measured ambient pressure. In this work we focus only on frost as the condensate, which is applicable to measurements at the low temperatures in the UT/LS.

Chilled mirror hygrometry provides an absolute measurement of water vapour with an accuracy that relies only on the calibration of the temperature sensor that measures the temperature of the mirror. This is true, however, only when two conditions are valid: (1) the surface reflectivity is inversely correlated with the amount of condensate, and (2) the saturation vapour pressure of the condensate layer remains that of pure hexagonal ice. A change in the composition of the surface of the frost by incorporation of other compounds could potentially invalidate one or both conditions, which would then affect the determination of ambient water vapour. There are several trace gases in the UT/LS less abundant than water vapour that are likely to interact with the frost layer. One is $\mathrm{HNO}_{3}$, with mixing ratios ranging from less than 0.1 parts per billion (ppb) to several ppb (Neuman et al., 2001; Popp et al., 2009). A number of laboratory studies have shown that $\mathrm{HNO}_{3}$ adsorbs readily to ice surfaces (Zondlo et al., 1997; Abbatt, 2003; Ullerstam et al., 2005) and can form a thermodynamically stable, nitric acid hydrate condensed phase, such as nitric acid trihydrate $\left(\mathrm{HNO}_{3} \cdot 3 \mathrm{H}_{2} \mathrm{O}\right.$, NAT), under appropriate partial pressure and temperature conditions
(Worsnop et al., 1993). $\mathrm{HNO}_{3}$ has been observed in cirrus cloud particles (e.g. Popp et al., 2004; Voigt et al., 2006) and contrail particles (Schäuble et al., 2009) and proposed to explain the increase in the relative humidity over ice observed in cirrus clouds (Gao et al., 2004). Szakáll et al. (2001) observed during an AIDA chamber (a large volume aerosol and cloud simulation chamber in Karlsruhe, Germany) study that the addition of nitrogen dioxide $\left(0.01 \mathrm{~Pa}\right.$ of $\mathrm{NO}_{2}$, corresponding to more than $0.5 \mathrm{ppm})$ to the cold $(202 \mathrm{~K})$ chamber containing $5.5 \mathrm{ppm} \mathrm{O}_{3}$ resulted in an increase in the frost point temperature measured by a chilled mirror hygrometer and, hence, an overestimate of the water vapour mixing ratio. In their study, the CMH signal was compared with two other independent water-vapour measurement techniques that provided evidence that the chamber water vapour remained constant while the $\mathrm{CMH}$ response changed. They hypothesized that adsorption of $\mathrm{HNO}_{3}$, formed from $\mathrm{N}_{2} \mathrm{O}_{5}$ hydrolysis on sulphuric acid aerosols present in the chamber, led to conversion of the hygrometer frost to NAT. NAT on the mirror would raise the apparent frost point because it has a condensation temperature several degrees higher than pure water ice (Hanson and Mauersberger, 1988; Tolbert and Middlebrook, 1990; Worsnop et al., 1993).

In the present study, we report a laboratory evaluation of the interference of $\mathrm{HNO}_{3}$ in $\mathrm{CMH}$ frost point measurements under pressure, flow, and $\mathrm{HNO}_{3}$ conditions representative of operation in the UT/LS.

\section{Experimental}

\subsection{Chilled mirror hygrometer}

The chilled mirror hygrometers evaluated in this study are a reconfiguration of the Cryogenic Frostpoint Hygrometer $(\mathrm{CFH})$ sonde instrument. The $\mathrm{CFH}$ is a small $(400 \mathrm{~g})$ balloon-borne instrument that has been used extensively to measure water vapour profiles between the surface and the middle stratosphere at a number of locations around the globe. The stated accuracy in the determination of the frost point temperature is $\pm 0.5^{\circ} \mathrm{C}$ (Vömel et al., 2007), which corresponds to approximately $\pm 0.2 \mathrm{ppm}$ under UT/LS conditions, and the overall uncertainty near the tropopause is estimated to be $9 \%$. The $\mathrm{CFH}$ units used in this laboratory evaluation (Fig. 1) were copies of the modified version previously employed in the AquaVIT chamber study. The modified housing is made of stainless steel and has a similar geometry to that of the balloon-borne instrument, but is hermetically sealed to allow sample flow at UT/LS pressures $(<200 \mathrm{hPa})$. The optical path of the laboratory instrument has the light emitting diode (LED) source and infrared (IR) photodiode detector arranged at smaller $\left(\sim 40^{\circ}\right)$ angles to the mirror surface. This arrangement allows for imaging of the mirror surface with a microscope camera through a sapphire window mounted directly opposite the mirror. The LED, IR 


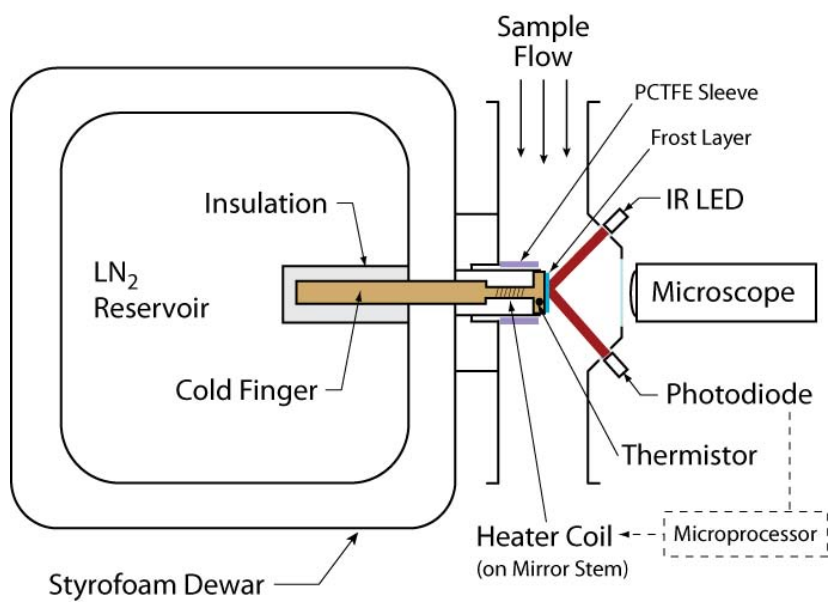

Fig. 1. Schematic of the laboratory $\mathrm{CFH}$ instruments used for the $\mathrm{HNO}_{3}$ experiments. Drawing not to scale.

photodiode detector, and electronics were used unmodified from a standard $\mathrm{CFH}$ instrument.

The dimensions of the mirror, mirror stem and heater coil are identical to the balloon instrument as is the location of the mirror thermistor. However, a mirror mount was made of thin-walled $(0.127 \mathrm{~mm})$ stainless-steel tube $1.6 \mathrm{~cm}$ long, which was glued to the edge of the mirror disk and acted both as a seal and thermal separation from the housing, since the body of the housing remained at room temperature. The low thermal conductivity of the tube assures that the thermal properties of the mirror assembly are similar to those of the balloon instrument. A PCTFE (Kel-F) sleeve was placed around the mirror mount to insulate it from the sample flow. The cold finger, the part of the mirror assembly that is immersed in the cryogen to provide mirror cooling is longer than that of the balloon instrument, since the fittings for connection to the flow system necessitated a larger separation between the cryogen reservoir and the sensor housing. The cooling rate of the mirror, which is largely determined by the dimensions of the thin mirror stem, remained unchanged. All key operational parameters of the laboratory version, including proportional, integral, and differential values of the temperature control loop, are identical to those in the balloon instrument. The laboratory $\mathrm{CFH}$ was operated using liquid nitrogen as the cryogen instead of trifluoromethane $\left(\mathrm{CHF}_{3}\right)$ as used with the balloon version. A Teflon sleeve and foam collar were placed over the cold finger to reduce the heat transfer rate into the cryogen. This insulation largely compensated for the colder temperature of the liquid nitrogen as indicated by mirror heater currents and duty cycles that are comparable to those observed in flight instruments.

\section{$2.2 \mathrm{HNO}_{3}$ measurement}

The $\mathrm{NO}_{\mathrm{y}}$ instrument used here to measure $\mathrm{HNO}_{3}$ is described in detail elsewhere (Fahey et al., 1989). The $\mathrm{NO}_{\mathrm{y}}$ instrument has been used previously in the stratosphere during several field campaigns (e.g., Fahey et al., 1989; Kawa et al., 1992). $\mathrm{HNO}_{3}$ and other $\mathrm{NO}_{\mathrm{y}}$ compounds are measured by conversion to $\mathrm{NO}$ in a $300{ }^{\circ} \mathrm{C}$ gold tube catalyst in the presence of CO (Fahey et al., 1985), followed by detection of the NO using $\mathrm{NO} / \mathrm{O}_{3}$ chemiluminescence. The sensitivity of the instrument was determined during each experiment by adding $\mathrm{NO}$ upstream of the catalytic converter from a gas standard with a known mixing ratio. Background signals in the chemiluminescence detector were subtracted prior to calculation of $\mathrm{HNO}_{3}$ mixing ratios. The overall uncertainty in the $\mathrm{HNO}_{3}$ measurement is $20 \%$. There is no interference in the $\mathrm{NO}_{\mathrm{y}}$ measurement from water vapour mixing ratios in the range used here.

\subsection{Experimental setup}

The experimental setup used to evaluate the potential interference of gas-phase $\mathrm{HNO}_{3}$ on the performance of chilled mirror hygrometers is shown in Fig. 2. The system consists of two identical hygrometers (described above) connected in series, sources of low mixing ratios of water vapour and $\mathrm{HNO}_{3}$, the $\mathrm{NO}_{\mathrm{y}}$ instrument, and the pressure control and pumping unit. The flow system manifold consisted of $1.58 \mathrm{~cm}$ inner diameter (ID) stainless steel tube sections connected with ISO-KF16 fittings. A distance of $23.5 \mathrm{~cm}$ separated the two CFH mirrors. A mass flow controller (Tylan FC-261) was used to deliver a stable flow of synthetic air (Scott Specialty Gases, Zero Air) through the system. The water vapour content of the zero air was determined to be less than $0.3 \mathrm{ppm}$ for all cylinders used. The total gas flow rate through the manifold in most experiments was $\sim 2000$ standard $\left(0{ }^{\circ} \mathrm{C}, 1013.25 \mathrm{hPa}\right) \mathrm{cm}^{3} \mathrm{~min}^{-1}(\mathrm{sccm})$, but experiments were conducted with flows between 1200 and $6000 \mathrm{sccm}$. Pressures were measured using 100 and 1000 Torr capacitance manometers (MKS, Inc. 626B Baratron). The pressure sensor used to monitor the pressure of the gas flowing past the frost point mirrors was attached to the flow tube about $20 \mathrm{~cm}$ downstream of the second $\mathrm{CFH}$ instrument. The flow tube ID remained $1.58 \mathrm{~cm}$ from the frost point hygrometers to the pressure sensor and no significant pressure gradient is expected under this configuration.

Two methods were used to add water vapour to the manifold sample flow. The first was a zero air flow $(20 \mathrm{sccm})$ past a temperature-controlled water vapour permeation tube (Kin-Tek Laboratories, HRT 010.00). The permeation source provided 1.9 to $5.7 \mu \mathrm{g} \mathrm{min}^{-1}$ of water vapour for temperatures between 60 and $80^{\circ} \mathrm{C}$, respectively. When added to the main sample flow, water vapour mixing ratios were adjustable in the range of 1 to $4 \mathrm{ppm}$, depending on the sample flow rate. The second method was to add a small flow of 


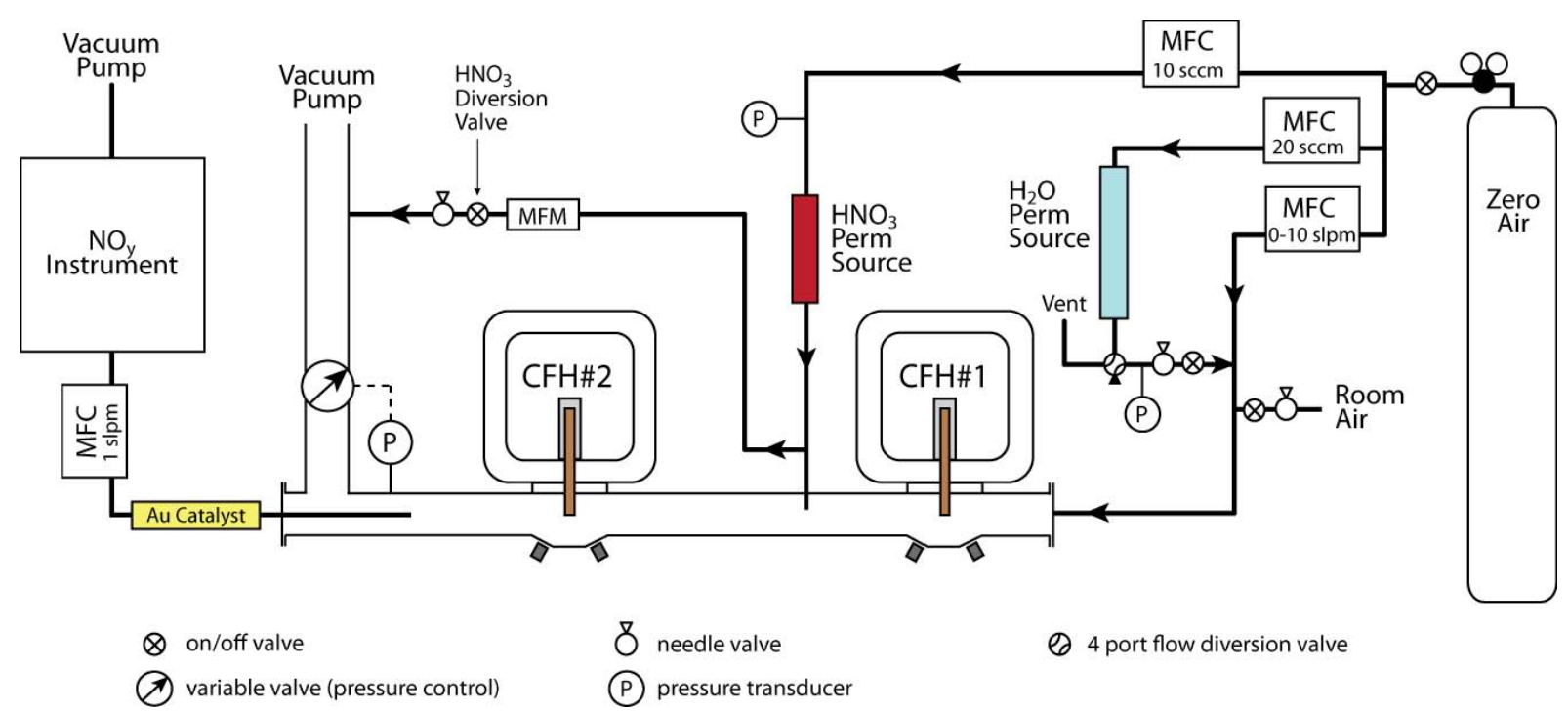

Fig. 2. Experimental set-up for the $\mathrm{HNO}_{3}$-frost point tests showing the arrangement in the manifold of the hygrometer mirrors, $\mathrm{HNO}_{3}$ addition point, and $\mathrm{NO}_{\mathrm{y}}$ sampling inlet. MFC is a mass flow controller operating at the specified flow or within the given flow range; MFM is a mass flow meter. Drawing not to scale.

room air into the manifold through a needle valve. This allowed higher mixing ratios of water vapour (up to $20 \mathrm{ppm}$ ) in the flow system. Given the water vapour content of lab air ( $>6000 \mathrm{ppm}$ ), this flow was at most a few sccm, $\ll 1 \%$ of the total system flow. During experiments, the value of the water vapour mixing ratio in the flow system was determined using the measured frost point temperature from the upstream $\mathrm{CFH}$ instrument.

$\mathrm{HNO}_{3}$ was added to the sample flow manifold using a $10 \mathrm{sccm}$ flow of zero air past a $\mathrm{HNO}_{3}$ permeation source (Kin-Tek Laboratories, SRT-002.00-2022/40) operated at either room temperature or $40^{\circ} \mathrm{C} . \mathrm{HNO}_{3}$ permeation sources are known to emit a small amount of $\mathrm{NO}_{2}$ or other $\mathrm{NO}_{\mathrm{y}}$ species along with the $\mathrm{HNO}_{3}$. The non- $\mathrm{HNO}_{3}$ emission was determined by measuring the $\mathrm{NO}_{\mathrm{y}}$ signal after passing the permeation source flow through a plug of nylon wool, which completely scrubs $\mathrm{HNO}_{3}$ from the flow. The residual (non$\mathrm{HNO}_{3}$ ) signal, which was $\sim 5 \%$ of the $\mathrm{NO}_{\mathrm{y}}$ signal without the nylon wool in line, was subtracted from the measured $\mathrm{NO}_{\mathrm{y}}$ signal to determine the $\mathrm{HNO}_{3}$ mixing ratio during experiments. The $\mathrm{HNO}_{3}$ addition point was located between the two CFH units in order to expose only the downstream unit (Fig. 2). The sampling point for the $\mathrm{NO}_{\mathrm{y}}$ instrument was located $15 \mathrm{~cm}$ downstream of the second CFH mirror. The inner surfaces of the flow tubes were coated from the $\mathrm{HNO}_{3}$ addition point between the hygrometers to a distance past the $\mathrm{NO}_{\mathrm{y}}$ sampling point with a thin film of FluoroPel (Cytonix Inc., PFC 504A-FS) to minimize $\mathrm{HNO}_{3}$ adsorption on the walls. $\mathrm{HNO}_{3}$ transmission through the flow system was determined by comparing the $\mathrm{NO}_{\mathrm{y}}$ signal with $\mathrm{HNO}_{3}$ added to the flow system with that observed when the $\mathrm{HNO}_{3}$ flow was added to the $\mathrm{NO}_{\mathrm{y}}$ instrument sample flow immediately in front of the catalyst. After 10-20 min, typical transmission values were $\geq 85 \%$. $\mathrm{HNO}_{3}$ addition to the flow system was controlled using a vacuum line connected to the $\mathrm{HNO}_{3}$ flow line immediately upstream of the manifold. When the valve in this auxiliary line was closed, flow past the $\mathrm{HNO}_{3}$ permeation tube was added to the manifold flow. When the valve in this auxiliary line was opened, the $\mathrm{HNO}_{3}$ flow was diverted away from the flow system to the vacuum pump along with a small amount of air from the flow system. Opening and closing this valve resulted in prompt addition or removal of $\mathrm{HNO}_{3}$ in the flow system.

One difference between a CFH instrument operating in the atmosphere on a balloon sonde and in our laboratory experiments is that in the former the temperatures of the sample flow and housing walls are near ambient as the altitude changes while in the latter they remain at room temperature. This difference is not expected to significantly affect the results of our experiments because it is the mirror surface that controls the temperature of absorbing and desorbing molecules. This result follows from a consideration that the molecular mean free path $(<1 \mu \mathrm{m})$ is much smaller than the thickness of the laminar-flow thermal boundary layer $(\sim 1 \mathrm{~mm})$ over the mirror surface and much smaller than the characteristic mirror dimension $(1 \mathrm{~cm})$.

\section{Results and discussion}

\subsection{Frost point interference}

$\mathrm{HNO}_{3}$ exposure tests were conducted first by allowing both hygrometers to achieve a stable frost layer at low water 


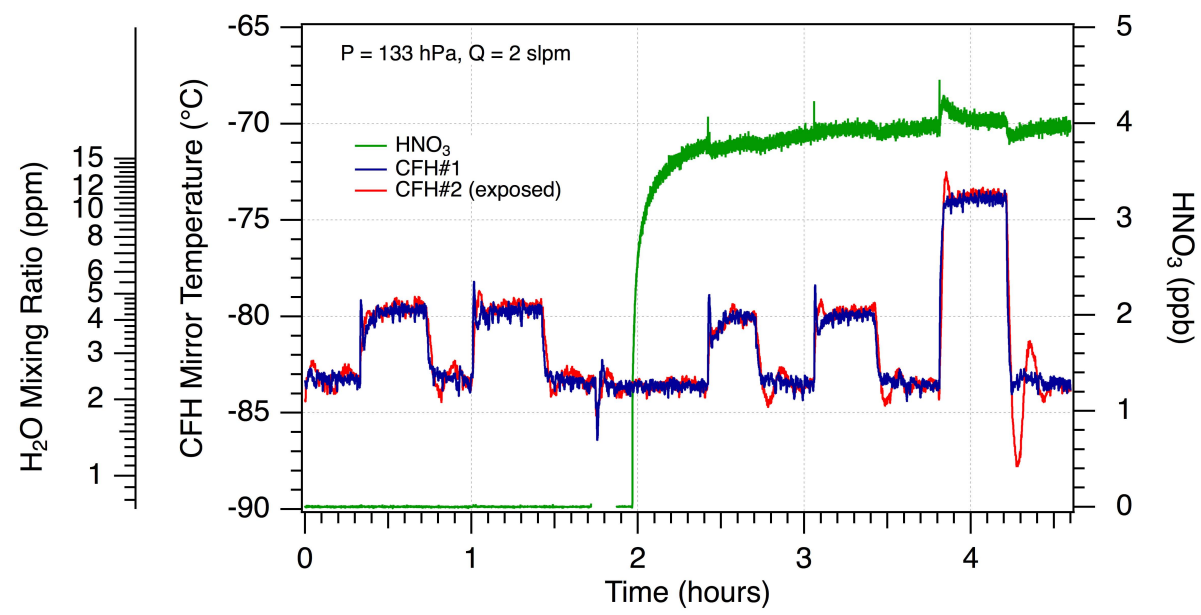

Fig. 3. Time series showing the reported frost point temperatures from both $\mathrm{CFH}$ instruments prior and subsequent to the addition of $\mathrm{HNO}_{3}$ to the sample flow and the $\mathrm{HNO}_{3}$ mixing ratio in the flow system as measured with the $\mathrm{NO}_{\mathrm{y}}$ detector. Increases in observed frost point temperature (water vapour mixing ratios) were due to addition of small flows of room air to the sample flow. Frost point temperatures measured by the exposed $\mathrm{CFH}$ before and after $\mathrm{HNO}_{3}$ addition agreed to within $0.1^{\circ} \mathrm{C}$.

vapour conditions $(1-5 \mathrm{ppm})$ in the absence of $\mathrm{HNO}_{3}$ and determining the $\mathrm{NO}_{\mathrm{y}}$ instrument background. $\mathrm{HNO}_{3}$ was then added to the manifold and the behaviour of the two $\mathrm{CFH}$ instruments was compared to evaluate the possible interference. A typical experimental run lasting $\sim 4 \mathrm{~h}$ is shown in Fig. 3. In this experiment, the permeation source was used to produce a constant background water vapour mixing ratio of $2.3 \pm 0.2 \mathrm{ppm}$ in the sample flow as measured consistently by both $\mathrm{CFH}$ units. The absolute value determined from the CFH measurements agreed to within $10 \%$ of the value calculated from the manufacturer's stated permeation rate. The higher water vapour values shown in Fig. 3, up to 4.3 and $11 \mathrm{ppm}$, were produced by periodically opening a valve (shown in Fig. 2) to admit a small flow of air from the room. The two CFH units exhibited slightly different transient responses to the rapid increases and decreases in water vapour, but reported the same value (within $0.3 \mathrm{ppm}$ ) upon reaching steady state after a few minutes.

Just before $2 \mathrm{~h}$ in the time series in Fig. 3, the $\mathrm{HNO}_{3}$ diversion valve was closed, thereby exposing the downstream CFH unit, $\# 2$, to $\mathrm{HNO}_{3}$. The $\mathrm{HNO}_{3}$ mixing ratio in the sample flow rapidly reached $3.5 \mathrm{ppb}$ and then continued to increase gradually over the next $2 \mathrm{~h}$. The long rise time for $\mathrm{HNO}_{3}$ is caused by the strong adsorption of $\mathrm{HNO}_{3}$ to all exposed surfaces, particularly those not covered by the Fluoropel coating. The variations observed in the $\mathrm{HNO}_{3}$ mixing ratio are due to slight changes in $\mathrm{HNO}_{3}$ transmission through the flow system that arise from changes in surface wetness and mirror temperature, and mirror frost evaporation and condensation related to rapid changes in water vapour. The frost point temperature reported by $\mathrm{CFH \# 2}$ never deviated significantly from that of $\mathrm{CFH \# 1}$, even after a 2.5 -h exposure of up to $4 \mathrm{ppb}$ of $\mathrm{HNO}_{3}$. Furthermore, the transient and steady state responses of CFH\#2 to the periods of increased water vapour were unchanged following $\mathrm{HNO}_{3} \mathrm{ex}-$ posure. A typical CFH balloon flight to $30 \mathrm{~km}$ altitude typically requires less than $2 \mathrm{~h}$ and $\mathrm{HNO}_{3}$ is typically $<0.5 \mathrm{ppb}$ in the middle and upper troposphere and gradually increases to $4 \mathrm{ppb}$ within a few kilometres above the tropopause (Popp et al., 2009). Thus, based on several experimental runs similar to that shown in Fig. 3, over a range of UT/LS conditions, there is no interference $\left(<0.1^{\circ} \mathrm{C}\right.$ frost point change) due to ambient $\mathrm{HNO}_{3}$ in $\mathrm{CMH}$ balloon sonde measurements.

\section{2 $\mathrm{HNO}_{3}$ surface coverage}

$\mathrm{HNO}_{3}$ is known to deposit readily to ice surfaces at temperatures similar to those of the CFH mirrors in these experiments in both the laboratory (Abbatt, 2003) and atmosphere (Popp et al., 2004; Voigt et al., 2006). The lack of any observed interference of $\mathrm{HNO}_{3}$ on the measured frost point temperature raises the question of the amount of $\mathrm{HNO}_{3}$ that accumulates on the frost during exposure. By rapidly heating the $\mathrm{CFH}$ mirror and vaporizing the frost layer after a certain $\mathrm{HNO}_{3}$ exposure time, any adsorbed or co-condensed $\mathrm{HNO}_{3}$ on the mirror is released into the sample flow and detected by the $\mathrm{NO}_{\mathrm{y}}$ instrument. Separate tests showed that mirror heating did not desorb appreciable $\mathrm{HNO}_{3}$ from surfaces of the insulated mirror mount (Fig. 1). A similar rapid mirror evaporation is typically programmed to occur during balloon ascent of the $\mathrm{CFH}$ instrument to ensure the condensate layer is frost and not supercooled liquid (Vömel et al., 2007). The resulting pulses of $\mathrm{HNO}_{3}$ measured by the $\mathrm{NO}_{\mathrm{y}}$ instrument can be clearly seen in the plot in Fig. 4. Examination of the $\mathrm{NO}_{\mathrm{y}}$ trace in Fig. 4 reveals that the magnitude of the desorbed $\mathrm{HNO}_{3}$ pulses is a function of the exposure time. The mass of adsorbed $\mathrm{HNO}_{3}$ was determined by integrating the pulse measured by the $\mathrm{NO}_{y}$ instrument. 


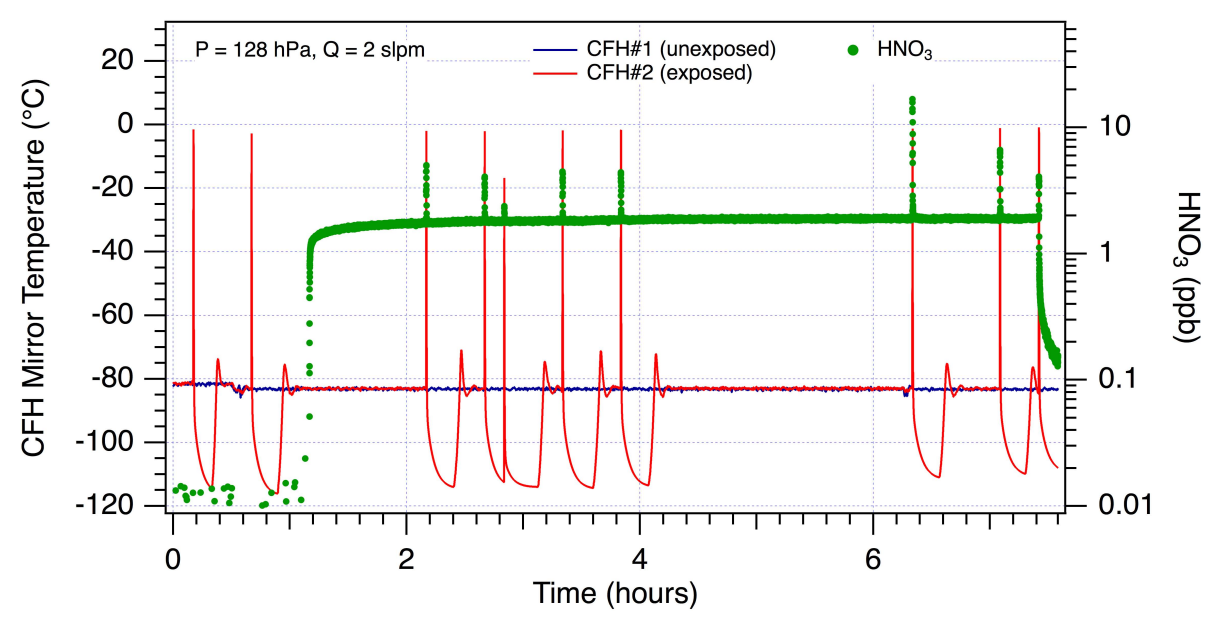

Fig. 4. Time series of $\mathrm{CFH}$ mirror temperatures and $\mathrm{HNO}_{3}$ mixing ratios. The stable mirror temperature corresponds to a water vapour mixing ratio of $2.5 \mathrm{ppm}$. The pulses visible in the $\mathrm{CFH \# 2}$ mirror temperature are rapid increases used to evaporate the frost layer. Corresponding pulses were observed in $\mathrm{HNO}_{3}$ as measured by the $\mathrm{NO}_{y}$ instrument when the frost layer had been exposed to $\mathrm{HNO}_{3}$. The negative excursions in the CFH\#2 temperature occur when the frost layer is being reformed following removal.

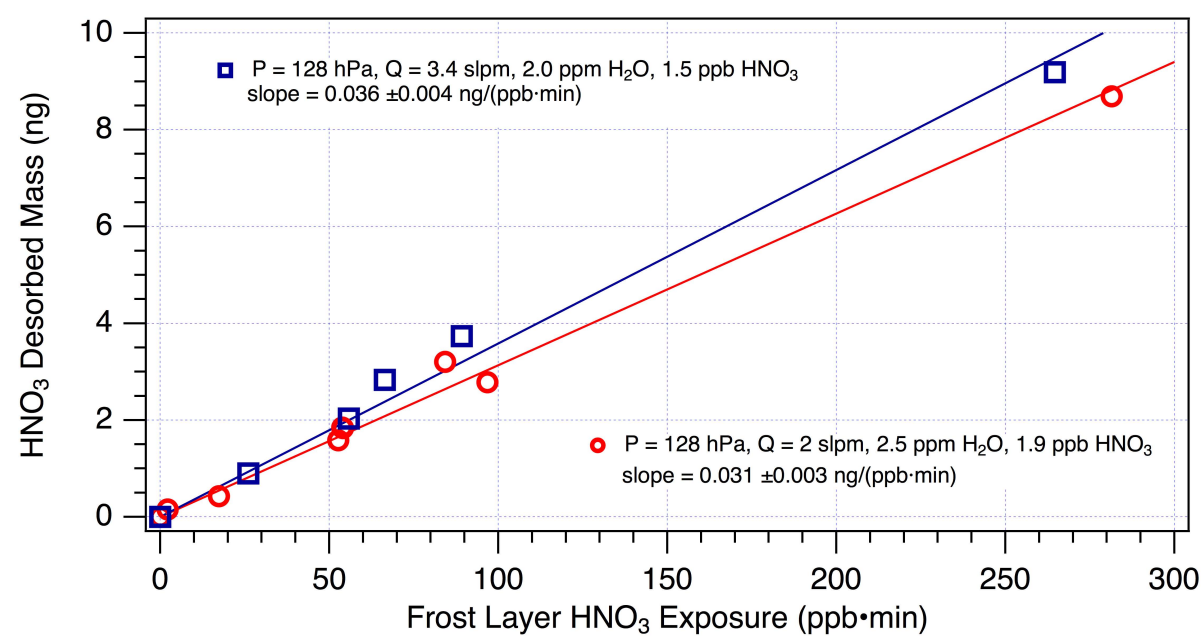

Fig. 5. Mass of $\mathrm{HNO}_{3}$ measured during mirror frost layer evaporation events plotted against the frost layer exposure to $\mathrm{HNO}_{3}$ expressed as the time integrated mixing ratio. The legend shows the experimental conditions of pressure, sample flow $(Q)$, and water vapour and $\mathrm{HNO}_{3}$ mixing ratios, along with the derived growth rate from the best fit line with a zero intercept.

Figure 5 shows the measured mass of desorbed $\mathrm{HNO}_{3}$ plotted against the exposure expressed as the product of the $\mathrm{HNO}_{3}$ mixing ratio and exposure time. $\mathrm{HNO}_{3}$ accumulated approximately linearly with exposure at mixing ratios of up to $4 \mathrm{ppb}$ over time periods up to $3 \mathrm{~h}$. Laboratory studies have shown $\mathrm{HNO}_{3}$ monolayer densities to be approximately $1-2 \times 10^{14}$ molecules $\mathrm{cm}^{-2}$ (Abbatt, 2003), so the highest observed $\mathrm{HNO}_{3}$ mass loadings $(\sim 8 \mathrm{ng})$ in our experiments represent roughly monolayer coverage of the geometric surface area of the mirror $\left(0.37 \mathrm{~cm}^{2}\right)$. There is no information on the specific surface area $\left(\mathrm{cm}^{2} \mathrm{~cm}^{-2}\right)$ of the frost, but based on electron micrographs recently published by Leu and Keyser (2009) of frost layers formed by water vapour deposition at similar temperatures, it is likely to be $\gg 1$. This implies that only a small fraction of the surface area of the frost is affected by $\mathrm{HNO}_{3}$ adsorption and, therefore, no significant interference in the $\mathrm{CFH}$ measurement would be expected.

\subsection{Thermodynamic considerations}

$\mathrm{H}_{2} \mathrm{O}$ adsorption and desorption on the frost layer are close to steady state when the water vapour concentration is constant above the mirror surface and the $\mathrm{CFH}$ mirror temperature is at a nearly constant value; under these conditions the frost layer is neither growing nor shrinking significantly. In contrast, $\mathrm{HNO}_{3}$ adsorption and desorption are clearly not 
in steady state, as evidenced by the time dependence of the $\mathrm{HNO}_{3}$ mass loading shown in Fig. 5. The state of the adsorbed $\mathrm{HNO}_{3}$ molecules is not known for the frost layer in our experiments. However, the mirror temperature and $\mathrm{H}_{2} \mathrm{O}$ and $\mathrm{HNO}_{3}$ partial pressures present in these experiments fall thermodynamically within the region of stable NAT formation (Hanson and Mauersberger, 1988; Tolbert and Middlebrook, 1990; Worsnop et al., 1993; Zondlo et al., 1997). The estimated small fractional $\mathrm{HNO}_{3}$ coverage of the frost surface area suggests that while NAT may exist locally on the frost surface or within the frost layer, the total $\mathrm{HNO}_{3} / \mathrm{H}_{2} \mathrm{O}$ molar ratio on the mirror is much less than 0.33 , which would be required for complete conversion of the frost to NAT. The $\mathrm{HNO}_{3}$ mixing ratios in our experiments represent a large supersaturation with respect to NAT at the mirror frost point temperatures (e.g. the ratio of the partial pressure of $\mathrm{HNO}_{3}$ to the saturation vapour pressure over NAT is $\sim 60$ for the conditions in the experiments shown in Fig. 5). The observed linear increase in $\mathrm{HNO}_{3}$ adsorbed mass in the first hours of exposure indicates that the molar ratio may continue to increase with time until it reaches 0.33 in the frost, or perhaps in a layer at the frost surface, which would bring $\mathrm{HNO}_{3}$ adsorption and desorption into steady state. If the NAT formation on the surface of the frost were to inhibit further formation of water ice, the CFH would then attempt to control at the NAT saturation temperature, several degrees higher than the frost point temperature under pure $\mathrm{H}_{2} \mathrm{O}$ conditions (Hanson and Mauersberger, 1988; Tolbert and Middlebrook, 1990; Worsnop et al., 1993) and the mirror temperature would then lead to an overestimate of the water vapour partial pressure. The ppb-min exposure of $\mathrm{HNO}_{3}$ required to reach NAT stoichiometry in the mirror frost appears to be much larger than that realized in this laboratory evaluation and, hence, is much larger than is relevant for $\mathrm{CFH}$ balloon-borne measurements. The interpretation of the interference in the reading of a commercial frost point instrument observed in the AIDA chamber was that $\mathrm{HNO}_{3}$ had accumulated in sufficient amounts to convert the frost to NAT (Szakáll et al., 2001). The results presented here cannot confirm or disprove their interpretation since their experiment was conducted with much higher $\mathrm{HNO}_{3}$ levels.

\section{Conclusions}

Two CFH frost point hygrometers and an $\mathrm{NO}_{y}$ instrument were used to investigate the potential interference of gasphase nitric acid $\left(\mathrm{HNO}_{3}\right)$ at atmospherically-relevant mixing ratios in measurement of low ppm water vapour mixing ratios by chilled mirror hygrometers under pressure and flow conditions representative of operation in the UT/LS. No detectable change $\left(< \pm 0.1^{\circ} \mathrm{C}\right)$ in the measured $\mathrm{CFH}$ frost point temperature was found with additions of up to $4 \mathrm{ppb} \mathrm{HNO}_{3}$ for periods exceeding $2 \mathrm{~h} . \mathrm{HNO}_{3}$ that had adsorbed or co-condensed on the mirror with $\mathrm{H}_{2} \mathrm{O}$ was detected during rapid frost layer evaporation using the $\mathrm{NO}_{\mathrm{y}}$ instrument. Our measured $\mathrm{HNO}_{3}$ loadings of the $\mathrm{CFH}$ mirror surface indicate that over a typical balloon-borne $\mathrm{CFH}$ ascent period (90-120 min), condensed $\mathrm{HNO}_{3}$ mass increased linearly at a rate of $0.033 \mathrm{ng}$ $\min ^{-1} \mathrm{ppb}^{-1}$. The observed mass loading of $\sim 8 \mathrm{ng}$ following 120 min exposure at $2 \mathrm{ppb} \mathrm{HNO}_{3}$ corresponds to approximately monolayer coverage of the geometric mirror surface area, but likely much less than monolayer coverage of the frost surface area. We conclude that for typical atmospheric conditions, it is unlikely that $\mathrm{HNO}_{3}$ alone could cause a significant error in water vapour measured by a balloon-sonde chilled-mirror hygrometer such as the CFH. The potential for $\mathrm{HNO}_{3}$ to interfere with $\mathrm{CMH}$ water vapour measurement during extended sampling in the lower stratosphere from aircraft or other balloon platforms is likely small, but would require further study to critically assess.

Acknowledgements. This work was supported by funding from the NOAA Climate Program Office. We would like to thank Christiane Voigt for valuable discussions and suggestions.

Edited by: H. Schlager

\section{References}

Abbatt, J. P. D.: Interactions of atmospheric trace gases with ice surfaces: adsorption and reaction, Chem. Rev., 103, 4783-4800, 2003.

Dessler, A. E., Zhang, Z., and Yang, P.: Water-vapor climate feedback inferred from climate fluctuations, 2003-2008, Geophys. Res. Lett., 35, L20704, doi:10.1029/2008GL035333, 2008

Fahey, D. W., Kelly, K. K., Ferry, G. V., Poole, L. R., Wilson, J. C., Murphy, D. M., Loewenstein, M., and Chan, K. R.: In situ measurements of total reactive nitrogen, total water, and aerosol in a polar stratospheric cloud in the Antarctic, J. Geophys. Res., 94, 11299-11315, 1989.

Forster, P. M. de F. and Shine, K. P.: Assessing the climate impact of trends in stratospheric water vapor, Geophys. Res. Lett., 29(6), 1086, doi:10.1029/2001GL013909, 2002.

Gao, R. S., Popp, P. J., Fahey, D. W., Marcy, T. P., Herman, R. L., Weinstock, E. M., Baumgardner, D. G., Garrett, T. J., Rosenlof, K. H., Thompson, T. L., Bui, P. T., Ridley, B. A., Wofsy, S. C., Toon, O. B., Tolbert, M. A., Kärcher, B., Peter, Th., Hudson, P. K., Weinheimer, A. J., and Heymsfield, A. J.: Evidence that nitric acid increases relative humidity in low-temperature cirrus clouds, Science, 303, 516-520, 2004.

Gettelman, A., de Forster, P. M. F., Fujiwara, M., Fu, Q., Vömel, H., Gohar, L. K., Johanson, C., and Ammerman, M.: Radiation balance of the tropical tropopause layer, J. Geophys. Res., 109, D07103, doi:10.1029/2003JD004190, 2004.

Hanson, D. R. and Mauersberger, K.: Laboratory studies of the nitric acid trihydrate: Implications for the south polar stratosphere, Geophys. Res. Lett., 15, 855, 1988.

Held, I. M. and Soden, B. J.: Water vapour feedback and global warming, Annu. Rev. Energ. Environ., 25, 441-475, 2000. 
Hurst, D. F., Oltmans, S. J., Vömel, H., Rosenlof, K. H., Davis, S. M., Ray, E. A., Hall, E. G., and Jordan, A. F.: Stratospheric water vapor trends over Boulder, Colorado: Analysis of the 30 year Boulder record, J. Geophys. Res., 116, D02306, doi:10.1029/2010JD015065, 2011.

Jensen, E. J., Smith, J. B., Pfister, L., Pittman, J. V., Weinstock, E. M., Sayres, D. S., Herman, R. L., Troy, R. F., Rosenlof, K., Thompson, T. L., Fridlind, A. M., Hudson, P. K., Cziczo, D. J., Heymsfield, A. J., Schmitt, C., and Wilson, J. C.: Ice supersaturations exceeding $100 \%$ at the cold tropical tropopause: implications for cirrus formation and dehydration, Atmos. Chem. Phys., 5, 851-862, doi:10.5194/acp-5-851-2005, 2005.

Kawa, S. R., Fahey, D. W., Kelly, K. K., Dye, J. E., Baumgardner, D., Gandrud, B. W., Loewenstein, M., Ferry, G. V., and Chan, K. R.: The Arctic polar stratospheric cloud aerosol - aircraft measurements of reactive nitrogen, total water, and particles, J. Geophys. Res., 97, 7925-7938, 1992.

Leu, M.-T. and Keyser, L. F.: Vapor-deposited water and nitric acid ices: Physical and chemical properties, Int. Rev. Phys. Chem., 28, 53-109, doi:10.1080/01442350802617129, 2009.

Neuman, J. A., Gao, R. S., Fahey, D. W., Holecek, J. C., Ridley, B. A., Walega, J. G., Grahek, F. E., Richard, E. C., McElroy, C. T., Thompson, T. L., Elkins, J. W., Moore, F. L., and Ray, E. A.: In situ measurements of $\mathrm{HNO}_{3}, \mathrm{NO}_{\mathrm{y}}, \mathrm{NO}$, and $\mathrm{O}_{3}$ in the lower stratosphere and upper troposphere, Atmos. Environ., 35, 5789-5797, 2001.

Oltmans, S., Rosenlof, K., Michelsen, H. A., Schiller, C., Read, W. G., Nedoluha, G. E., Pan, L., Remsberg, E. E., Bates, J. J., Bevilacqua, R. M., Chanin, M.-L., Chiou, E.-W., Chu, W. P., Fischer, H., Johnson, D. G., Gordley, L. L., Hartogh, P., Helten, M., Herman, R. L., Hintsa, E. J., Ismail, S., Kanzawa, H., Kelly, K. K., Kley, D., May, R. D.,Miloshevich, L. M., Oelhaf, H., Ovarlez, J., Pumphrey, H. C., Purcell, P. N., Russell III, J. M., Sachse, G. W., Sherlock, V.,Smit, H. G. J., Toon, G. C., Vay, S. A., Vömel, H., and Weinstock, E. M.: Chapter 2: Data Quality, in: SPARC Assessment of Upper Tropospheric and Stratospheric Water Vapour, edited by: Kley, D., Russell III, J. M., and Phillips, C., 2000a.

Oltmans, S. J., Vömel, H., Hofmann, D. J., Rosenlof, K. H., and Kley, D.: The increase in stratospheric water vapor from balloonborne, frostpoint hygrometer measurements at Washington, DC, and Boulder, Colorado, Geophys. Res. Lett., 27, 3453-3456, 2000b.

Peter, T., Marcolli, C., Spichtinger, P., Corti, T., Baker, M. B., and Koop, T.: When dry air is too humid, Science, 314, 1399-1402, 2006.

Popp, P. J., Gao, R. S., Marcy, T. P., Fahey, D. W., Hudson, P. K., Thompson, T. L., Kärcher, B., Ridley, B. A., Weinheimer, A. J., Knapp, D. J., Montzka, D. D., Baumgardner, D., Garrett, T. J., Weinstock, E. M., Smith, J. B., Sayres, D. S., Pittman, J. V., Dhaniyala, S., Bui, T. P., and Mahoney, M. J.: Nitric acid uptake on subtropical cirrus cloud particles, J. Geophys. Res., 109, D06302, doi:10.1029/2003JD004255, 2004.

Popp, P. J., Marcy, T. P., Gao, R. S., Watts, L. A., Fahey, D. W., Richard, E. C., Oltmans, S. J., Santee, M. L., Livesey, N. J., Froidevaux, L., Sen, B., Toon, G. C., Walker, K. A., Boone, C. D., and Bernath, P. F.: Stratospheric correlation between nitric acid and ozone, J. Geophys. Res., 114, D03305, doi:10.1029/2008JD010875, 2009.
Rosenlof, K. H., Oltmans, S. J., Kley, D., Russel III, J. M., Chiou, E.-W., Chu, W. P., Johnson, D. G., Kelly, K. K., Michelsen, H. A., Nedoluha, G. E., Remsberg, E. E., Toon, G. C., and McCormick, M. P.: Stratospheric water vapor increases over the past half-century, Geophys. Res. Lett., 28, 1195-1198, 2001.

Schäuble, D., Voigt, C., Kärcher, B., Stock, P., Schlager, H., Krämer, M., Schiller, C., Bauer, R., Spelten, N., de Reus, M., Szakáll, M., Borrmann, S., Weers, U., and Peter, Th.: Airborne measurements of the nitric acid partitioning in persistent contrails, Atmos. Chem. Phys., 9, 8189-8197, doi:10.5194/acp-98189-2009, 2009.

Soden, B. J. and Held, I. M.: An assessment of climate feedbacks in coupled ocean-atmosphere models, J. Climate, 19, 3354-3360, 2006.

Solomon, S., Rosenlof, K., Portmann, R., Daniel, J., Davis, S., Sanford, T., and Plattner, G.-K.: Contributions of stratospheric water vapor to decadal changes in the rate of global warming, Science, 327, 1219, doi:10.1126/science.1182488, 2010.

Szakáll, M., Bozoki, Z., Kraemer, M., Spelten, N., Moehler, O., and Schurath, U.: Evaluation of a Photoacoustic Detector for Water Vapor Measurements under Simulated Tropospheric/Lower Stratospheric Conditions, Environ. Sci. Technol., 35, 4881-4885, 2001.

Tolbert, M. A. and Middlebrook, A. M.: Fourier Transform Infrared Studies of Model Polar Stratospheric Cloud Surfaces' Growth and Evaporation of Ice and Nitric Acid/Ice, J. Geophys. Res., 95, 22423-22431, 1990.

Trenberth, K. E., Jones, P. D., Ambenje, P., Bojariu, R., Easterling, D., Klein Tank, A., Parker, D., Rahimzadeh, F., Renwick, J. A., Rusticucci, M., Soden, B., and Zhai, P.: Observations: Surface and Atmospheric Climate Change, in: Climate Change 2007: The Physical Science Basis, Contribution of Working Group I to the Fourth Assessment Report of the Intergovernmental Panel on Climate Change, edited by: Solomon, S., Qin, D., Manning, M., Chen, Z., Marquis, M., Averyt, K. B., Tignor, M., and Miller, H. L., Cambridge University Press, Cambridge, UK and New York, NY, USA, 2007.

Ullerstam, M., Thornberry, T., and Abbatt, J. P. D.: Uptake of gasphase nitric acid to ice at low partial pressures: evidence for unsaturated surface coverage, Faraday Discuss., 130, 211-226, 2005.

Vömel, H., David, D. E., and Smith, K.: Accuracy of tropospheric and stratospheric water vapour measurements by the cryogenic frost point hygrometer: Instrumental details and observations, J. Geophys. Res., 112, D08305, doi:10.1029/2006JD007224, 2007.

Voigt, C., Schlager, H., Ziereis, H., Kärcher, B., Luo, B. P., Schiller, C., Krämer, M., Popp, P. J., Irie, H., and Kondo, Y.: Nitric acid in cirrus clouds, Geophys. Res. Lett., 33, L05803, doi:10.1029/2005GL025159, 2006.

Worsnop, D. R., Fox, L. E., Zahniser, M. S., and Wofsy, S. C.: Vapor Pressures of Solid Hydrates of Nitric Acid: Implications for Polar Stratospheric Clouds, Science, 259, 71-74, 1993.

Zondlo, M. A., Barone, S. B., and Tolbert, M. A.: Uptake of $\mathrm{HNO}_{3}$ on ice under upper tropospheric conditions, Geophys. Res. Lett., 24, 1391-1394, 1997. 